\title{
Psychotropic Medications Affecting Biological Rhythm
}

\author{
Elif Oral ${ }^{1}$, Halil Ozcan², Mustafa Gulec ${ }^{1}$, Yavuz Selvi ${ }^{3}$, Adem Aydin ${ }^{3}$
}

ÖZET:

Biyolojik ritmi etkileyen psikotrop ilaçlar

Birçok canlı organizmada, omurgalı ve memeli canlıda oldug̃u gibi insanda da biyolojik ișlevler çeșitli aralıklarla salınan ritimlerle yürür. Sirkadyen, ultradien ve infradian ya da daha uzun aralıklarla salınan iç ritimlerimiz kendi iç düzenlerini her șartta devam ettiren, bag̃ımsız biyolojik organizasyonlardır. Biyolojik olarak kendiliḡinden ișleyen, istikrarlı bir yol varsa da, gerek psikiyatrik hastalıklar ve gerekse de psikotrop ilaçlar bu iç ritimleri deg̃iş̧irebilir. Psikotrop ilaçlar, etki düzeneklerindeki nörotransmmitter ya da nöromediatörler vasıtasıyla dog̃rudan veya daha uzun vadede hormonal ya da genetik deg̃ișikliklere neden olarak da biyolojik ritimler üzerine etkili olabilir. Biyolojik ritim düzensizliklerinin duygudurum bozuklukları açısından hem neden hem de sonuç olarak önemine dikkat çeken birçok çalışma vardır. Duygudurum bozukluklarının takip ve tedavisinde psikofarmakolojik ajanların biyolojik ritimlere olan muhtemel etkisi de deg̃erlendirilmesi önemlidir.

Anahtar sözcükler: kronobiyotikler, psikotrop ilaçlar, biyolojik ritim

Journal of Mood Disorders 2011;1(4):169-77

\section{ABSTRACT:}

Psychotropic medications affecting biological rhythm

There are many biological rhythms with various time oscillations regulating biological functions in living organisms, mammalians, and humans. Biological rhythms such as circadian, ultradian, and infradian or with longer cycles are independent biological organizations rather than dependent to the external stimulus. Although there is a sustained biological rhythmicity, psychiatric disorders and psychotropic drugs can change this process. The effects of psychotropics on biological rhythmicity can occur via possible neurotransmitter and neuromediator mechanisms within a relatively short time period on the other hand hormonal or genetic mechanisms can impact long term outcome. So far several studies suggested that biological rhythm disturbances play an important role in etiology and course of mood disorders'. Assessment of the possible effects of psychopharmacological agents on biological rhythm is important during the course of mood disorders.

Key words: chronobiotics, psychotropic medications, biological rhythm

Journal of Mood Disorders 2011;1(4):169-77
${ }^{1} \mathrm{MD}$, Assistant Professor, Department of Psychiatry, Faculty of Medicine, Ataturk University, Erzurum-Turkey ${ }^{2} \mathrm{MD}$, Specialist, Department of Psychiatry, Ministry of Health, Dr. Zekai Tahir Burak Women's Health Training and Research Hospital, Ankara-Turkey Hospital, Ankara-Turkey
${ }^{3} \mathrm{MD}$, Assistant Professor, Department of Psychiatry, Faculty of Medicine, Yuzuncu Yil University, Van-Turkey

Yazısma Adresi / Address reprint requests to: Elif Oral, Department of Psychiatry, Faculty of Medicine, Atatürk University, Erzurum 25240 Turkey

Telefon / Phone: +90-442-231-6954 Faks / Fax: +90-442-236-1301

Elektronik posta adresi / E-mail address: oralelif@yahoo.com

Kabul tarihi / Date of acceptance: 20 Aralık 2011 / December 20, 2011

Bag̃ıntı beyanı:

E.O., H.O., M.G., Y.S., A.A.: Yazarlar bu makale ile ilgili olarak herhangi bir çıar çatıșması bildirmemișlerdir.

Declaration of interest:

E.O., H.O., M.G., Y.S., A.A.: The authors reported no conflict of interest related to this article.

\section{INTRODUCTION}

\section{Biological Rhythms}

Many behaviors (e.g. sleep-wake, feeding) as well as physiological (e.g. body temperature, blood pressure) and endocrine (e.g. plasma corticosteroid concentration) events display a $24 \mathrm{~h}$ rhythmicity in mammals. These $24 \mathrm{~h}$ rhythms are induced by a timing system that is composed of central and peripheral clocks (1).The suprachiasmatic nucleus (SCN) of the hypothalamus is the central pacemaker or the master clock (2). The SCN receives input from many other brain areas and also has efferents towards many areas, several of them to the hypothalamus (3). Lesions of the SCN disturb circadian rhythmicity in a variety of behavioral, endocrine, and biochemical processes (4). Aside from the circadian endogenous rhythms, there are endogenous rhythms with shorter periods, ranging from seconds to hours, called ultradian rhythms, as well as longer rhythms lasting from a week or a month to a year. There are unsolved questions as to the role of the SCN in relation to these other rhythms. SCN lesions suppress some but not all ultradian rhythms. These lesions also modify the seasonal rhythm of reproduction of several mammals $(5,6)$. SCN lesions in rats suppress the scale-invariant patterns of motor activity within a 4-24-hour time range, which suggests a general role of the SCN in rhythm generation, i.e. not only for circadian rhythms (7). Although light is the most important zeitgeber that directly influences the output of multiple oscillator systems, SCN together with peripheral clocks, enables a time-related homeostasis in case the 
external time cues such as daylight are not available (5). Despite, there is a biological sustainability, psychiatric disorders and also psychotropic medications have important effects on synchronizations of biological clocks (8-11).

\section{Biological Rhythms and Psychiatry}

The major marked clinical feature in affective disorders is their periodic nature, in a large range from seasonal depression to rapid cycling of bipolar disorders (12). "In winter depression," the most common form of seasonal affective disorder, patients experience major depressive episodes beginning with the onset of winter, followed by remission or even hypomania in the spring $(13,14)$. Also, many patients with non-seasonal depression show a regular daily pattern of symptoms, usually symptoms are more severe in the mornings (15). Suicide rates also show both diurnal and seasonal variations (16). Phase-advanced oscillations in plasma cortisol and norepinephrine compared to healthy subjects, and abnormal levels and patterns of melatonin secretion may reflect the fundamental signs of disturbed biological rhythms in depressed patients (17-19). There is clinical and epidemiological evidence that sleep disturbances in depression constitute a risk factor for poor clinical outcomes. Specifically, complaints of insomnia precede the onset and recurrence of depression (20). Some researchers found shortening in Rapid Eye Movement (REM) sleep latency in bipolar disorder not only in depressive episode but also in mania. Furthermore, there was great variability of sleep duration and increased nocturnal time awakening in remitted BPD outpatients (21). Some studies conducted on drug free patients, found that decreased sleep efficiency, reduced total sleep time, and elevated sleep latency in schizophrenia (22).

\section{Chronopharmacology}

Because it is not the main topic of this review, we only included brief information about definition and clinical importance to ensure familiarity with the concept of chronopharmacology. Even the amount of drug entering into the brain is the same, the effects may vary depending on the time of entry. This suggests presence of a rhythm in drug susceptibility of the brain (23).
Chronopharmacology is the investigative science that elucidates the impact of biological rhythms on medications from both chronopharmacodynamic and chronopharmacokinetic perspectives (24). For example, effects and side effects of Interferons (IFNs) may dramatically change with their administration time (25). IFNs have been widely used as antiviral and antitumor agents. IFNs can cause some neuropsychiatric side effects such as depression and in some research, their use was found related to higher suicide attempts $(26,27)$. When IFNs are administrated in the morning they are rapidly removed from the plasma and their interactions with effector cells are decreased at the administration time. Furthermore, IFN may cause a secondary cortisol peak and related side effects about 6-8 hour after administration time $(28,29)$. Similarly the effect of the 5-HT uptake blocker, clomipramine is stronger at noon in humans. This may be due to an increase in 5-HT release around noon time (30). Chronopharmacodynamic and chronopharmacokinetic factors also have important effects on efficacy and side effect profile of other psychotropic medications such as Valproic Acid (VA) (31).

\section{Chronobiotics}

Chronobiotic is defined as a substance that "adjusts the timing of internal biological rhythms" or "a substance that may adjusts or prevent the timing of the central biological clock" (32).

\section{Psychotropic Drug Effects on Clock Genes}

Clock genes have an important role on the regulation of circadian rhythms. These genes include Clock, Bmall (ARNTL), period genes (Per1, 2, 3), cryptochrome genes (Cry1, 2), casein kinase Ie (CSNK1e) and Rev-erb-a (Nrld1) (33,34). The mRNA levels of numerous core clock genes change in depression including cryptochrome (CRY1, CRY2), period (PER1, PER2, PER3), BMAL1 (ARNTL), and CLOCK. A sleep deprivation study in BPD (Bipolar Disorder) depressed patients indicated a reduction in baseline CRY2 mRNA levels compared to controls $(35,36)$. Following one night of sleep deprivation CRY2 mRNA levels increased 2-fold in controls but did not significantly change in depressed subjects (37). Mice with a mutation in Clock (Clock D19) have manic-like 
behaviours which can be suppressed by lithium $(38,39)$. A follow-up study in mice with a knockdown of Clock in the ventral tegmental area documented changes in activity which the investigators interpreted as a mixed state of manic and depressive behaviors. In these animals, locomotor activities were increased in response to novel stimuli yet overall activity in the home cage was decreased (40). It is challenging to report that the Clock mutation phenotype can be suppressed by melatonin (or the melatonin agonist, ramelteon) to stabilize circadian rhythms (41).

\section{Effects of Antidepressants on Sleep}

Before the assessment of the each antidepressant group, it is necessary to review possible effects of the major neurotransmitters on sleep. Serotonin is a major neurotransmitter that has modulatory effects on the regulation of sleep and wakefulness. Serotonergic systems have a substantial role on maintenance of wakefulness, the induction of sleep, and the changeover from Non Rapid Eye Movement (NREM) to REM sleep $(42,43)$. It was assumed that the serotonergic neurons are active during the awareness, inactive during Slow Wave Sleep (SWS), and are particularly quiescent during REM sleep. As there are several types and subtypes of serotonin receptors in the receptor families, it is not easy to predict the exact effects of the serotonergic system on sleep (44). Under this circumstance, is it then correct to claim " the serotonergic system supports to initiation of sleep?" Although on one hand this opinion is correct, on the other hand "serotonergic system may induce a hypodopaminergic state, which can cause movement disorders and hence increased arousal and/or sleep onset insomnia." Noradrenaline (NA) and DA Dopamine (DA) are related to the awareness and DA also related with alertness. NA activity is highest level during the wakefulness, inactive during SWS, and extremely silent during REM sleep in that related with inactive muscle tone (45).

In this review, some psychotropic drugs with well known sleep inducing effects and commonly used effectively, such as benzodiazepines are excluded. Also some drugs such as Agomelatine mentioned briefly, because our main point was not just limited with chronotherapeutics.

\section{Tricyclic Antidepressants (TCAs)}

Although there are an individual differences, TCAs generally shorten sleep latency and improve sleep continuity in depressed patients, and their sleep inducing effects can cause daytime drowsiness. Most TCAs suppress REM sleep, increase REM latency and reduce the percentage of REM sleep, thus tending to normalize the disturbed sleep architecture seen in depressed patients (46). Amitriptyline and Doxepin increase sleep continuity and suppress REM sleep, and their sedative effects are distinct. Clomipramine has no significant sleep sustaining or sedative effect, but it has clearly suppressive effect on REM sleep (47). Until the late eighties, there are several published studies suggested that the antidepressant activity across different drugs was found to be related to their capacity to suppress REM sleep and suppression of REM sleep is the key mechanism of action of antidepressant drugs and REM sleep is depressogenic (48-51). At present, it is only possible to say that REM sleep changes with antidepressant medications may reflect underlying circadian effects (46).

\section{Selective Serotonin Reuptake Inhibitors (SSRIs)}

It has been suggested that SSRI use can reach degree of agitation and akathisia through the $5 \mathrm{HT} 2 \mathrm{~A}$ receptor sites in some patients (43). Approximately $25 \%$ of depressed patients enrolled in clinical trials with SSRIs reported subjective complaints of insomnia (47). SSRIs have dose dependent effect disruption of sleep continuity and daytime somnolence (52). Fluoxetine clearly suppresses REM this action commonly sustained to the 4 weeks of treatment. It also decreases to sleep efficiency, and increase number of awakenings $(47,53)$. Fluoxetine produced resistant phase advances of the peak ofSCN neuronal activity (54). Melatonin metabolized by CYP1A2 to 6-hydroxymelatonin and $\mathrm{N}$-acetylserotonin with a minimal contribution of CYP2C19. Because of the both reactions were potently inhibited by Fluvoxamine, it can suggest that melatonin effects enhanced by Fluvoxamine (55). Paroxetine clearly suppresses REM sleep, both among healthy volunteers and depressed patients. Paroxetine suppresses REM, decreases total sleep time, and increases awakenings $(47,53,56)$. Sertraline and Citalopram have less disruptive effects on sleep continuity because of their less activating effects $(47,57)$. 


\section{Bupropion}

It has effective via NA and DA reuptake inhibition. It decreases REM latency and increases total percentage of REM, and improve sleep efficiency (58).

\section{Venlafaxine and Duloxetine}

At lower doses, Venlafaxine has significantly sleep disturbing effects like SSRIs, and it caused by possibly effects of serotonin reuptake inhibition $(47,59,60)$. Although $60 \mathrm{mg} /$ day Duloxetine reduced to sleep continuity, $80 \mathrm{mg} /$ day Duloxetine had significant improvement in sleep, and it has been emphasized that dose dependent change in SNRI effects on sleep continuity (61).

\section{Mirtazapine}

This special molecule has been opposite effects with SSRIs. SSRIs can cause to the behavioral activation, anxiety, sleep disturbances via 5-HT2A stimulation, whereas Mirtazapine has opposite effects on these dimensions. Similarly, Mirtazapine does not cause the irritability or loss of appetite via 5-HT2C stimulation, although SSRIs do it. Similar to the antihistaminic agents, Mirtazapine's sleep promoting effect is rapid, and it can cause daytime sedation. Although histaminergic blockage helps to rapid sleep onset, it is assumed that the effects on continuity is due to its 5HT2 and 5HT3 blocking effects $(62,63)$.

\section{Trazodone}

There is no REM suppressive effect due to its weak 5 -HT reuptake inhibition. Its hypnotic dose range is 50-200 mg, although antidepressant dosage should be three times more (64).

\section{Melatonin and Melatonin Agonists}

Melatonin is a hormone synthesized by the pineal gland. Its secretion occurs only at night in both diurnal and nocturnal mammals (65). Circadian rhythm regulation via SCN, depends on the regularly secretion of pineal melatonin and existence of healthy melatonin receptors in SCN as well (66). In healthy subjects, DimLight Melatonin Onset (DLMO) occurs 1-2 h before sleep onset. In depressed patients, DLMO is usually delayed and melatonin levels are decreased $(67,68)$. In depressive patients there are some single nucleotide polymorphisms (SNPs) in the melatonin pathway such as arylalkylamine $\mathrm{N}$-acetyltransferase (AANAT) (69) and a rate-limiting melatonin enzyme acetylserotonin methyltransferase (ASMT) (70). Melatonin is a prototype of chronobiotics and the chemical code of darkness (43). The effects of melatonin on SCN activity are mediated by at least two receptors; MT2 receptors that sensitive at dusk and dawn and causes phase shifts, and MT1 receptors that decreases the neuronal firing rate at early evening $(71,72)$.

\section{Ramelteon}

It is a selective MT1 and MT2 receptor agonist. It has both sleep-promoting and chronobiotic effects (73).

\section{Agomelatine}

Agomelatine has no effects on pre or post synaptic 5 HT1A receptors and its mechanism of action is different from TCA and SSRIs. Agomelatine is significantly effective on a several behavioral models of antidepressant properties, such as forced-swim test (74), the learned helplessness paradigm in rats (75), the olfactory bulbectomized rat model (76), and the chronic mild stress test (77). In the chronic mild stress model, agomelatine remains effective independently of the administration time, shows that its antidepressant activity is not only due to its action at melatonergic receptors, but also related to the antagonistic activity at 5-HT2C receptors.

\section{Mood Stabilizers}

\section{Carbamazepine}

It was shown to increase SWS and decrease REM sleep. This study was conducted with 7 temporal lobe epilepsy patients and 9 healthy controls. In both groups, fragmentation of REM and increase in sleep shifts were observed (78). Another article reported increased SWS and sleep efficacy, decreased awakenings, and decreased sleep latency (79). However, there are some studies reporting no difference in sleep architecture with carbamazepine $(80,81)$. 


\section{Valproic Acid (VA)}

In a study, it was found that VA increases Stage 1, decreases stage 2 sleep, causes difficulty in initiating sleep, and reduces REM sleep (82), while the another study reported that VA has a little or no effect on sleep architecture (83).

\section{Lithium}

Lithium lengthens circadian rhythm period in plants, rodents, and mammalians including humans (84). Although the knowledge about the Lithium's efficacy in sustaining Sleep Deprivation Treatment (SDT) improvement is not new, current studies are more detailed and clarified the mechanism of action (85- 89). Benedetti reported that patients who had been treated with Lithium longer than 6 months showed more sustained improvement in SDT than drug free patients (88). It was also observed lithium treated patients with the short allele of the serotonin transporter gene (5-HTTLPR $\mathrm{s} / \mathrm{s}$ variant) had better responses to SDT than those with the short allele and not treated with lithium (89). Although long term lithium treatment ineffective to prevent the recurrence major depressive episodes, it was able to sustain the clinical improvement associated with sleep deprivation (90).

\section{Antipsychotics}

Although dopamine plays an important role in generation of awakeness, some selective dopamine antagonists such as pimozide and sulpiride has little effect on the sleep of healthy subjects (91). The sedative and sleep-inducing effects of antipsychotics arise from their antiadrenergic, antihistaminergic and anticholinergic capacities (92). Atypical (such as Quetiapine or Olanzapine) and typical (such as Levopromazine or Chlorpromazine) antipsychotic effects on total sleep time are related to their serotonergic and histaminergic affinity. Olanzapine increases SWS and it has been associated with blockage of the 5HTC2 receptor sites (93). There is a controversial issue whether the atypical antipsychotics has special effects on prolactin peaks or not, although it has been known they clearly show increasing effects on prolactin levels $(94,95)$. Systemic and intrahypothalamic prolactin increases REM sleep in cats, rabbits, and rats (96). On the other hand,

\section{Table 1: Psychotropic medication effectson sleep}

\begin{tabular}{|c|c|c|c|c|c|c|c|c|c|c|}
\hline $\begin{array}{l}\text { Psychotropic } \\
\text { Medications }\end{array}$ & s1 & 52 & SWS & REM & SL & $\mathbf{R L}$ & TST & SC & Arousals & $\begin{array}{l}\text { Stage } \\
\text { shifts }\end{array}$ \\
\hline \multicolumn{11}{|l|}{ Antidepressants } \\
\hline Amitriptyline $(43,47,48)$ & & & $\uparrow$ & $\downarrow$ & $\downarrow$ & $\uparrow$ & $\uparrow$ & $\uparrow$ & $\downarrow$ & \\
\hline Imipramine $(43,46)$ & & & $\uparrow$ & $\downarrow$ & $\uparrow$ & $\uparrow$ & $\downarrow$ & - & $\uparrow$ & \\
\hline Clomipramine $(42,43)$ & & & $\uparrow$ & $\downarrow$ & & $\uparrow$ & & - & & \\
\hline Fluoxetine $(47,53)$ & & & - & $\downarrow$ & $\uparrow$ & $\uparrow$ & & $\downarrow$ & $\uparrow$ & \\
\hline Paroxetine $(47,53,56)$ & & & - & $\downarrow$ & $\uparrow$ & $\uparrow$ & & $\downarrow \uparrow ?$ & $\uparrow \downarrow ?$ & \\
\hline Sertraline $(47,57)$ & & & - & $\downarrow$ & $\uparrow$ & $\uparrow$ & $\downarrow$ & - & - & \\
\hline Trazodone (64) & & & $\uparrow$ & - & $\downarrow$ & & $\uparrow$ & $\uparrow$ & $\downarrow$ & \\
\hline Duloxetine (61) & & & & $\downarrow$ & $\uparrow$ & & & $\uparrow \downarrow "$ & & \\
\hline Venlafaxine $(47,59,60)$ & $\uparrow$ & & & $\downarrow$ & & $\uparrow$ & & $\downarrow$ & $\uparrow$ & \\
\hline Mirtazapine $(62,63)$ & & & & & $\downarrow$ & & $\uparrow$ & $\uparrow$ & $\downarrow$ & \\
\hline Anticonvulsants & & & & & & & & & & \\
\hline Valproic acid $(82,83)$ & $\uparrow$ & $\uparrow \downarrow ?$ & $\uparrow$ & $\downarrow$ & & & & & - & N/A \\
\hline Lamotrigine $(42,43)$ & N/A & $\uparrow$ & $\downarrow$ & $\uparrow$ & & & & & $\uparrow$ & $\downarrow$ \\
\hline Carbamazepine $(42,43,78,79)$ & N/A & N/A & $\uparrow$ & $\downarrow$ & $\downarrow$ & $\uparrow$ & $\uparrow$ & $\uparrow$ & $\downarrow$ & $\uparrow$ \\
\hline \multicolumn{11}{|l|}{ Antipsychotics } \\
\hline Clozapine $(42,43,92,93,102)$ & $\downarrow$ & $\uparrow$ & - & $\downarrow$ & & & $\uparrow$ & $\uparrow$ & & \\
\hline Quetiapine $(42,43,103)$ & & $\uparrow$ & & $\downarrow$ & $\downarrow$ & - & $\uparrow$ & $\uparrow$ & & \\
\hline Risperidone $(42,43,92)$ & & $\downarrow$ & $\uparrow$ & & & $\uparrow$ & & & $\downarrow$ & \\
\hline Olanzapine $(43,93,104)$ & $\downarrow$ & & $\uparrow$ & $\downarrow$ & $\downarrow$ & $\uparrow$ & $\uparrow$ & $\uparrow$ & $\downarrow$ & \\
\hline Haloperidol (43) & & & & & $\downarrow$ & & $\uparrow$ & $\uparrow$ & $\downarrow$ & \\
\hline
\end{tabular}


antiserum to prolactin decreases REM sleep in rats $(96,97)$. In patients with hyperprolactinoma, SWS is selectively increased compared to the controls (98). Repetitive ghrelin administration increases SWS, and also $\mathrm{GH}, \mathrm{ACTH}$, and cortisol levels increase after ghrelin, in young men (99). Intrahypothalamic ghrelin increases feeding and wakefulness in rats (100). In a patient with night-eating syndrome, nocturnal ghrelin levels appeared to be elevated (101). Psychotropic medication effects on sleep are summarized at table 1 .

\section{CONCLUSIONS}

Both known mechanism of action and every process within treatment are important in effects of psychotropic medications on biological rhythms. The psychotropic

\section{References:}

1. Kalsbeek A, Yi CX, Cailotto C, la Fleur SE, Fliers E, Buijs RM. Mammalian clock output mechanisms. Essays Biochem 2011; 30:49:137-151.

2. Klein DC. Moore RY. Reppert, SM. editors. Suprachiasmatic Nucleus: The Mind's Clock. Oxford University Press; New York: 1991.

3. Reuss S. Components and connections of the circadian timing system in mammals. Cell Tissue Res 1996; 285:353-378.

4. Turek FW. Circadian neural rhythms in mammals. Annu Rev Physiol 1985; 47:49-64.

5. Schulz P, Steimer T. Neurobiology of circadian systems. CNS Drugs 2009;23:3-13.

6. Hofman MA. The brain's calendar: neural mechanisms of seasonal timing. Biol Rev Camb Philos Soc 2004; 79: 61-77.

7. $\mathrm{Hu} \mathrm{K}$, Scheer FAJL, Ivanov PC. The suprachiasmatic nucleus functions beyond circadian rhythm generation. Neuroscience 2007;149:508-517.

8. Ebisawa T. Circadian rhythms in the CNS and peripheral clock disorders: human sleep disorders and clock genes. J Pharmacol Sci 2007; 103:150-154.

9. Toh KL. Basic science review on circadian rhythm biology and circadian sleep disorders. Ann Acad Med Singapore 2008; 37:662668.

10. Young ME, Bray MS. Potential role for peripheral circadian clock dyssynchrony in the pathogenesis of cardiovascular dysfunction. Sleep Med 2007; 8:656-667.

11. Monteleone P, Maj M. The circadian basis of mood disorders: recent developments and treatment implications. Eur Neuropsychopharmacol 2008; 18:701-711. effects on rhythms can effectively be used in acute and chronic treatment of mood disorders and also in maintenance for their protective effect. The efforts to find effective chronotherapeutic agents in psychiatric disorders reflect unmet needs in psychopharmacological management of disorders. On the other hand, it is impossible to think about effects and side effects of a medication independent from biological rhythms. One may say that while planning a psychopharmacological treatment strategy, the need to consider biological rhythm and related results has increased.

\section{Conflict of Interest}

None of the authors had any conflict of interest to declare.
12. Mizukawa R, Ishiguro S, Takada H, Kishimoto A, Ogura C, Hazama H. Long-term observation of a manic-depressive patient with rapid cycles. Biol Psychiatry 1991;29:671-678.

13. Saeed SA, Bruce TJ. Seasonal affective disorders. Am Fam Physician 1998; 57:1340-1346, 1351-1352.

14. Magnusson A, Partonen T. The diagnosis, symptomatology, and epidemiology of seasonal affective disorder. CNS Spectr 2005; 10:625-634.

15. Gordijn MC, Beersma DG, Bouhuys AL, Reinink E, Van den Hoofdakker RH. A longitudinal study of diurnal mood variation in depression; characteristics and significance. J Affect Disord 1994; 31:261-273.

16. Preti A, Miotto P, De Coppi M. Season and suicide: recent findings from Italy. Crisis 2000; 21:59-70.

17. Peeters F, Nicolson NA, Berkhof J. Levels and variability of daily life cortisol secretion in major depression. Psychiatry Res 2004; 126:1-13.

18. Karadottir R, Axelsson J. Melatonin secretion in SAD patients and healthy subjects matched with respect to age and sex. Int J Circumpolar Health 2001; 60:548-551.

19. Rabe-Jablonska J, Szymanska A. Diurnal profile of melatonin secretion in the acute phase of major depression and in remission. Med Sci Monit 2001; 7:946-952.

20. Gulec M, Selvi Y, Boysan M, Aydin A, Besiroglu L, Agargun MY Ongoing or re-emerging subjective insomnia symptoms after full/ partial remission or recovery of major depressive disorder mainly with the selective serotonin reuptake inhibitors and risk of relapse or recurrence: a 52-week follow-up study. J Affect Disord 2011;134 257-265. 
21. Salvatore P, Ghidini S, Zita G, De Panfilis C, Lambertino S, Maggini C, Baldessarini RJ. Circadian activity rhythm abnormalities in ill and recovered bipolar I disorder patients. Bipolar Disord 2008; 10:256-265.

22. Cohrs S. Sleep disturbances in patients with schizophrenia: impact and effect of antipsychotics. CNS Drugs 2008;22:939-962.

23. Nagayama H. Influences of Biological Rhythms on the Effects of Psychotropic Drugs Psychosomatic Medicine 1999; 61:618-629.

24. Ohdo S. Chronopharmacology Focused on Biological Clock. Drug Metab Pharmacokinet 2007; 22:3-14.

25. Ohdo S. Chronotherapeutic strategy: Rhythm monitoring, manipulation and disruption. Adv Drug Deliv Rev 2010; 62:859875.

26. Fattovich G, Giustina G, Favarato S, Ruol A. A survey of adverse events in 11241 patients with chronic viral hepatitis treated with alfa interferon. J Hepatol 1996; 24: 8-47.

27. Janssen HLA, Brouwer JT, Mast RC, Schalm SW. Suicide associated with alfa-interferon therapy for chronic viral hepatitis. J Hepatol 1994; $21:$ 41-243.

28. Bocci V. Distribution catabolism and pharmacokinetics of interferons, in: N.B. Finter, R. Oldham (editors), Interferon, Elsevier, Amsterdam, 1985:47-72.

29. Scott GM, Ward RJ, Wright DJ, Robinson JA, Onwubalili JK, Gauci CL. Effects of cloned interferon 2 in normal volunteers: febrile reactions and changes in circulating corticosteroids and trace metals. Antimicrob Agents Chemother1983; 23:589-592.

30. Nagayama H, Nagano K, Ikezaki A, Tashiro T. Double-blind study of the chronopharmacotherapy of depression. Chronobiol Int1991;8:203-209.

31. Ohdo S. Chronopharmaceutics: pharmaceutics focused on biological rhythm. Biol Pharm Bull 2010;33:159-167.

32. Arendt J, Skene D J. Melatonin as a chronobiotic. Sleep Med Rev $2005 ; 9,25-39$

33. Bunney WE, Bunney BG. Molecular clock genes in man and lower animals: possible implications for circadian abnormalities in depression. Neuropsychopharmacology 2000; 22:335-345.

34. Bunney JN, Potkin SG. Circadian abnormalities, molecular clock genes and chronobiological treatments in depression. Br Med Bull 2008;86:23-32.

35. Benedetti F, Dallaspezia S, Fulgosi MC, Lorenzi C, Serretti A, Barbini B, Colombo C, Smeraldi E. Actimetric evidence that CLOCK 3111 T/C SNP influences sleep and activity patterns in patients affected by bipolar depression. Am J Med Genet B Neuropsychiatr Genet 2007; 144:631-635.

36. Gouin JP, Connors J, Kiecolt-Glaser JK, Glaser R, Malarkey WB, Atkinson C, Beversdorf D, Quan N Altered expression of circadian rhythm genes among individuals with a history of depression. J Affect Disord 2010; 126:161-166.

37. Lavebratt C, Sjöholm LK, Partonen T, Schalling M, Forsell Y. PER2 variation is associated with depression vulnerability. Am J Med Genet B Neuropsychiatr Genet 2010; 153:570-581.
38. Dzirasa K, Coque L, Sidor MM, Kumar S, Dancy EA, Takahashi JS, McClung CA, Nicolelis MA. Lithium ameliorates nucleus accumbens phase-signaling dysfunction in a genetic mouse model of mania. J Neurosci 2010; 30:16314-16323.

39. Roybal K, Theobold D, Graham A, DiNieri JA, Russo SJ, Krishnan V, Chakravarty S, Peevey J, Oehrlein N, Birnbaum S, Vitaterna MH, Orsulak P, Takahashi JS, Nestler EJ, Carlezon WA Jr, McClung CA. Mania-like behavior induced by disruption of CLOCK. Proc Nat Acad Sci USA 2007; 104:6406-6411.

40. Mukherjee S, Coque L, Cao JL, Kumar J, Chakravarty S, Asaithamby A, Graham A, Gordon E, Enwright JF 3rd, DiLeone RJ, Birnbaum SG, Cooper DC, McClung CA. Knockdown of Clock in the ventral tegmental area through RNA interference results in a mixed state of mania and depression-like behavior. Biol Psychiatry 2010; 68:503-511.

41. Shimomura K, Lowrey PL, Vitaterna MH, Buhr ED, Kumar V, Hanna P, Omura C, Izumo M, Low SS, Barrett RK, LaRue SI, Green $\mathrm{CB}$, Takahashi JS. Genetic suppression of the circadian Clock mutation by the melatonin biosynthesis pathway. Proc Natl Acad Sci USA 2010; 107:8399-8403.

42. Jones BE. In: Kryger MH, Roth TR, Dement WC (editors). Principles and Practices of Sleep Medicine, 4 th edn. Philadelphia, PA: WB Saunders, 2005:136-53.

43. SR Pandi-Perumal, Joris C Verster, Jaime M Monti, Malcolm Lader, Salomon Z Langer (editors). Sleep Disorders: Diagnosis and Therapeutics. Christopher M Sinton and Robert W McCarley (chapter editors). Receptor mechanisms in sleep and wakefulness. Informa UK Ltd, 2008.

44. Hoyer D, Hannon JP, Martin GR. Molecular, pharmacological and functional diversity of 5-HT receptors. Pharmacol Biochem Behav 2002; 71:533-554.

45. Siegel JM. The neurotransmitters of sleep. J Clin Psychiatry 2004; 65:4-7.

46. Germain A, Kupfer DJ. Circadian rhythm disturbances in depression. Hum Psychopharmacol 2008;23:571-585.

47. Winokur A, Gary KA, Rodner S, Rae-Red C, Fernando AT, Szuba MP. Depression, sleep physiology, and antidepressant drugs. Depress Anxiety 2001; 14:19-28.

48. Rush AJ, Giles DE, Jarrett RB, Feldman-Koffler F, Debus JR, Weissenburger J, Orsulak PJ, Roffwarg HP. Reduced REM latency predicts response to tricyclic medication in depressed outpatients. Biol Psychiatry 1989;26:61-72.

49. Kupfer DJ, Spiker DG, Coble PA, Neil JF, Ulrich R, Shaw DH. Sleep and treatment prediction in endogenous depression. Am J Psychiatry 1981;138:429-434.

50. Vogel GW. Evidence for REM sleep deprivation as the mechanism of action of antidepressant drugs. Prog Neuropsychopharmacol Biol Psychiatry 1983;7:343-349.

51. Vogel GW, Buffenstein A, Minter K, Hennessey A. Drug effects on REM sleep and on endogenous depression. Neurosci Biobehav Rev 1990; 14:49-63.

52. DeMartinis NA, Winokur A. Effects of psychiatric medications on sleep and sleep disorders. CNS Neurol Disord Drug Targets 2006; 6:17-29. 
53. Sharpley AL, Cowen PJ. Effect of pharmacologic treatments on the sleep of depressed patients. Biol Psychiatry 1995; 37:85-98.

54. Sprouse J, Braselton J,Reynolds L. Fluoxetine modulates the circadian biological clock via phase advances of suprachiasmatic nucleus neuronal firing. Biol Psychiatry 2006; 60:896-899.

55. Härtter S, Wang X, Weigmann H, Friedberg T, Arand M, Oesch F, Hiemke C. Differential effects of fluvoxamine and other antidepressants on the biotransformation of melatonin. J Clin Psychopharmacol 2001;21(2):167-174.

56. Sharpley AL, Williamson DJ, Attenburrow ME, Pearson G, Sargent $P$, Cowen PJ. The effects of paroxetine and nefazodone on sleep: a placebo-controlled trial. Psychopharmacology (Berl) 1996; 126:5054.

57. Winokur A, Sewitch DE, Phillips JL, Biniaur IV. Sleep architecture and mood effects of sertraline in outpatients with major depression: a preliminary report. Biol Psychiatry 1991;29:163.

58. Nofzinger EA, Reynolds CF 3rd, Thase ME, Frank E, Jennings JR, Fasiczka AL, Sullivan LR, Kupfer DJ. REM sleep enhancement by buproprion in depressed men. Am J Psychiatry 1995; 152:274-276.

59. Salin-Pascual RJ, Galicia-Polo L, Drucker-Colin R. Sleep changes after 4 consecutive days of venlafaxine administration in normal volunteers. J Clin Psychiatry 1997; 58:348-350.

60. Peterson MJ, Benca RM. Sleep in mood disorders. Psychiatr Clin North Am 2006; 29:1009-1032.

61. Vincent S, Bieck PR, Garland EM, Loghin C, Bymaster FP, Black BK, Gonzales C, Potter WZ, Robertson D. Clinical assessment of norepinephrine transporter blockade through biochemical and pharmacological profiles. Circulation 2004; 109:3202-3207.

62. Nutt DJ. Tolerability and safety aspects of mirtazapine. Hum Psychopharmacol Clin Exp 2002; 17:37-41.

63. Winokur A, DeMartinis NA 3rd, McNally DP, Gary EM, Cormier JL, Gary KA. Comparative effects of mirtazapine and fluoxetine on sleep physiology measures in patients with major depression and insomnia. J Clin Psychiatry 2003; 64:1224-1229.

64. Wilson S, Argyropoulos S. Antidepressants and sleep. Drug 2005; 65:927-947.

65. Mendoza J, Challet E. Brain clocks: from the suprachiasmatic nuclei to a cerebral network. Neuroscientist 2009;15:477-488.

66. Pévet P, Agez L, Bothorel B, Saboureau M, Gauer F, Laurent V, Masson-Pévet M. Melatonin in the multi-oscillatory mammalian circadian world. Chronobiol Int 2006; 23:39-51.

67. Buckley TM, Schatzberg AF. A pilot study of the phase angle between cortisol and melatonin in major depression - a potential biomarker? J Psychiatr Res 2010; 44:69-74.

68. Lewy AJ. Depressive disorders may more commonly be related to circadian phase delays rather than advances: time will tell. Sleep Med 2010; 11:117-118.

69. Soria V, Martínez-Amorós E, Escaramís G, Valero J, Crespo JM, Gutiérrez-Zotes A, Bayés M, Martorell L, Vilella E, Estivill X, Menchón JM, Gratacòs M, Urretavizcaya M. Resequencing and association analysis of arylalkylamine $\mathrm{N}$-acetyltransferase (AANAT). Gene and its contribution to major depression susceptibility. J Pineal Res 2010; 49:35-44.
70. Gałecki P, Szemraj J, Bartosz G, Bieńkiewicz M, Gałecka E, Florkowski A, Lewiński A, Karbownik-Lewińska M. Singlenucleotide polymorphisms and mRNA expression for melatonin synthesis rate-limiting enzyme in recurrent depressive disorder. J Pineal Res 2010; 48:311-317.

71. Dubocovich ML, Markowska M. Functional MT1 and MT2 melatonin receptors in mammals. Endocrine 2005; 27:101-110.

72. Saper CB, Scammell TE, Lu J. Hypothalamic regulation of sleep and circadian rhythms. Nature 2005; 437:1257-1263.

73. Sateia MJ, Kirby-Long P, Taylor JL. Efficacy and clinical safety of ramelteon.: an evidence based review. Sleep Med Rev 2008;12:319-332.

74. Bourin M, Mocaer E, Porsolt R. Antidepressant-like activity of S 20098 (agomelatine) in the forced swimming test in rodents: involvement of melatonin and serotonin receptors. J Psychiatry Neurosci 2004; 29:126-133.

75. Bertaina-Anglade V, Drieu la Rochelle C, Boyer PA, Mocaer E. Antidepressant-like effects of agomelatine (S 20098) in the learned helplessness model. Behav Pharmacol 2006; 17:703-713.

76. Norman TR, Irons J, Cranston I. Effect of the novel antidepressant agomelatine in the olfactory bulbectomised rat. Int J Neuropsychopharmacol P02597, 2004; 7:2.

77. Papp M, Gruca P, Boyer PA, Mocaer E. Effect of agomelatine in the chronic mild stress model of depression in the rat. Neuropsychopharmacology 2003; 28:694-703.

78. Gigli GL, Placidi F, Diomedi M, Maschio M, Silvestri G, Scalise A, Marciani MG. Nocturnal sleep and daytime somnolence in untreated patients with temporal lobe epilepsy: changes after treatment with controlled-release carbamazepine. Epilepsia 1997; 38:696-701.

79. Gann H, Riemann D, Hohagen F, Müller WE, Berger M. The influence of carbamazepine on sleep-EEG and the clonidine test in healthy subjects: results of a preliminary study. Biol Psychiatry 1994; 35:893-896.

80. Declerck AC, Wauquier A. Influence of antiepileptic drugs on sleep patterns. In: Degen R, Rodin EA (editors). Epilepsy, Sleep and Sleep Deprivation, 2nd edn. Amsterdam: Elsevier Science Publishers, Amsterdam, 1991:153-163.

81. Manni R, Ratti MT, Galimberti CA, Morini R, Perucca E, Tartara A. Daytime sleepiness in epileptic patients on long-term monotherapy: MSLT, clinical and psychometric assessment. Neurophysiol Clin 1993;23:71-6.

82. Legros B, Bazil CW. Effects of antiepileptic drugs on sleep architecture: a pilot study. Sleep Med 2003;4:51-55.

83. Sammaritano M, Sherwin A. Effect of anticonvulsant on sleep. Neurology 2000; 54:16-24.

84. Justice A W, Benedetti F, Terman M. Chronotherapeutics for Affective Disorders: A Clinician's Manual for Light and Wake Therapy. S. Karger AG, PO Box, CH-4009 Basel. 2009:76.

85. Baxter LR. Can lithium carbonate prolong the antidepressant effect of sleep deprivation? Arch Gen Psychiatry 1985; 42:635.

86. Baxter LR Jr, Liston EH, Schwartz JM, Altshuler LL, Wilkins JN, Richeimer S, Guze BH. Prolongation of the antidepressant response to partial sleep deprivation by lithium. Psychiatry Res 1986; 19:17-23. 
87. Szuba MP, Baxter LR Jr, Altshuler LL, Allen EM, Guze BH, Schwartz JM, Liston EH. Lithium sustains the acute antidepressant effects of sleep deprivation: preliminary findings from a controlled study. Psychiatry Res 1994; 51:283-295.

88. Benedetti F, Colombo C, Barbini B, Campori E, Smeraldi E. Ongoing lithium treatment prevents relapse after total sleep deprivation. J Clin Psychopharmacol 1999; 19:240-245.

89. Benedetti F, Barbini B, Bernasconi A, Fulgosi MC, Campori E, Colombo C, Dallaspezia S, Lorenzi C, Pontiggia A, Radaelli D, Smeraldi E. Lithium overcomes the influence of 5-HTTLPR gene polymorphism on antidepressant response to sleep deprivation. J Clin Psychopharmacol 2008; 28:249-251.

90. Bunney BG, Bunney WE. Rapid-acting antidepressant strategies: mechanisms of action. Int J Neuropsychopharmacol 2011; 7:1-19.

91. Cohrs S. Sleep disturbances in patients with schizophrenia: impact and effect of antipsychotics. CNS Drugs 2008;22:939-962.

92. Gerlach J, Peacock L. New antipsychotics: the present status. Int Clin Psychopharmacol 1995; 10:39-48.

93. Sharpley AL, Attenburrow ME, Hafizi S, Cowen PJ. Olanzapine increases slow wave sleep and sleep continuity in SSRI-resistant depressed patients. J Clin Psychiatry 2005;66:450-454.

94. Vidarsdottir S, Roelfsema F, Frolich M, Pijl H. Olanzapine shifts the temporal relationship between the daily acrophase of serum prolactin and cortisol concentrations rhythm in healthy men. Psychoneuroendocrinology 2009; 34:705-712.

95. Yasui-Furukori N, Furukori H, Sugawara N, Tsuchimine S, Fujii A, Inoue Y, Kaneko S. Prolactin fluctuation over the course of a day during treatments with three atypical antipsychotics in schizophrenic patients. Hum Psychopharmacol 2010; 25:236-242.
96. Roky R, Valatx JL, Paut-Pagano L, Jouvet M. Hypothalamic injection of prolactin or its antibody alters the rat sleep-wake cycle. Physiol Behav 1994; 55:1015-1019.

97. Obál F Jr, Kacsóh B, Bredow S, Guha-Thakurta N, Krueger JM. Sleep in rats rendered chronically hyperprolactinemic with anterior pituitary grafts. Brain Res 1997; 755:130-136.

98. Frieboes RM, Murck H, Stalla GK, Antonijevic IA, Steiger A Enhanced slow wave sleep in patients with prolactinoma. J Clin Endocrinol Metab 1998; 83:2706-2710.

99. Weikel JC, Wichniak A, Ising M, Brunner H, Friess E, Held K, Mathias S, Schmid DA, Uhr M, Steiger A. Ghrelin promotes slowwave sleep in humans. Am J Physiol Endocrinol Metab 2003; 284:407-415.

100.Szentirmai E, Kapás L, Krueger JM. Ghrelin microinjection into forebrain sites induces wakefulness and feeding in rats. Am J Physiol Regul Integr Comp Physiol 2007; 292:75-85.

101.Rosenhagen MC, Uhr M, Schüssler P, Steiger A. Elevated plasma ghrelin levels in night-eating syndrome. Am J Psychiatry 2005; 162:813.

102. Cohrs S, Rodenbeck A, Guan Z, Pohlmann K, Jordan W, Meier A, Rüther E. Sleep-promoting properties of quetiapine in healthy subjects. Psychopharmacology (Berl). 2004;174:421-429.

103.Hinze-Selch D, Mullington J, Orth A, Lauer CJ, Pollmächer T. Effects of clozapine on sleep: a longitudinal study. Biol Psychiatry 1997 15; 42:260-266.

104. Sharpley AL, Vassalo CM, Cowen PJ. Olanzapine increases slowwave sleep: evidence for blockade of central 5-HT2C receptors in vivo. Biol Psychiatry 2000; 47:468-70. 